\title{
THE EFFECT OF TEMPEH EXTRACT GEL ON WOUND HEALING IN DIABETES \\ RAT: OVERVIEW OF TISSUE COLLAGEN, WOUND CLOSURE, EPITHELIALIZATION AND CAPILLARIZATION
}

\author{
Ignatius Adi Kurniawan, Rini Dwiastuti, Sri Hartati Yuliani*)
}

Magister Program of Pharmacy, Universitas Sanata Dharma, Kampus III Paingan Maguwoharjo Depok Sleman Yogyakarta, 55282, Indonesia

Received January 13, 2020; Accepted January 15, 2020

\begin{abstract}
The development of wound healing preparations in diabetes conditions needs to be done because the wound healing process in the respective conditions requires longer time. The aim of this study is to measure the effect of tempeh extract gel containing genistein on wound healing in diabetes rats by observing the response parameters of collagen expression, wound closure speed, epithelialization, and capillarization of wound tissue. The results of testing wound closure using a base gel treatment, tempeh extract gel $2.5 \%, 5 \%, 7.5 \%$ and without treatment indicated that the treated groups of tempeh extract gel $5 \%$ and $7.5 \%$ have significant effect on diabetes wound healing in the tested animals. This indication is strengthened by the results of the non-treatment groups statistical test with the 5\% and 7.5\% tempeh extract gel treatment which showed significant difference in influencing the wound closure response, epithelialization and collagen formation in tissue. The results of the statistical in group without treatment with the base treatment group without extract gel and tempeh extract gel $2.5 \%$ showed no significant difference in influencing the wound closure response, epithelialization and collagen formation. Statistical test results on capillarization responses indicated that the results were not significantly different from all treatment groups.
\end{abstract}

Keywords: diabetes; gel; tempeh extract; wound closure; wound healing.

\section{INTRODUCTION}

Diabetes Mellitus (DM) is a metabolic disorder caused by a decrease in the amount of insulin production from pancreatic cells. It is a chronic metabolic disorder in which the pancreas does not produce enough insulin or the body cannot use the available insulin effectively. This condition could increase glucose concentration in the blood (hyperglycemia). Indonesia ranks number 7 for the number of people with DM in the world. The cases of diabetes ulcer were found in $15 \%$ of people with DM in the world (Utami and Karim, 2014). DM conditions can cause disruption on wound healing process. Longer wound healing time is influenced by the increase of matrix metalloproteinase (MMP) and fibroblast activities in forming collagen (Sharp and Jane, 2011).

Tempeh is food made of soy that is very easy to get in Indonesia. The process of boiling and processing soybeans into tempeh can increase the level of isoflavones from soybeans (Utari, 2010). Genistein is one of the isoflavone compounds contained in soybeans that can be extracted and isolated (Agrawal et al., 2015). Genistein is known to have an influence on wound healing through various mechanisms. Administration of gel containing genistein can accelerate the wound healing process in experimental animals (Emmerson et al., 2010). The treatment of genistein is known to influence the wound healing process in test animals with DM conditions (Tie et al., 2013). 
Genistein contained in tempeh extract needs to be developed into a topical dosage form. So, it is necessary to conduct a test to measure tempeh extract effect in topical preparations on wound healing process in experimental animals with DM. The effect of administration is seen from the amount of collagen formed in wound healing.

The development of wound healing preparations in diabetes conditions needs to be done because wound healing process in diabetes conditions often encounters obstacles. It causes healing process to take a longer period. These obstacles include an increasing potential for infection due to decreasing neutrophil migration and prolonged inflammation. In this study, the observation of wound healing activities in diabetic rats was done by giving tempeh extract gel. This study aims to look at the effect of tempeh extract gel preparations to wound healing in diabetic rats with qualitative and quantitative observation parameters. The measured parameters to be observed were the collagen expression response, wound closure, epithelialization, and capillarization of wound tissue in the presence of tempeh extract gel containing genistein. The preparations used in this study were hydrogels, a form of preparation that can be used for wound care. This preparation has several benefits in closing wounds, maintaining moisture, and delivering medicinal ingredients (Gupta et al., 2011).

\section{METHODS}

\section{Materials and Instrument}

The materials included enisteinstandardized tempeh extract with levels of 429,055 $\mu \mathrm{g} / \mathrm{mL}$, ethanol, water, buffer citrate, streptozotocin (Cayman Chemical_USA), injection ketamine (Generic $\left.{ }^{\circledR}\right)$, neutral buffer formalin $10 \%$, and xylene. Test animals of male Wistar strain rats aged 2 months with a weight range of $150-180 \mathrm{~g}$ was obtained from the Center for Food and Nutrition of Gadjah Mada University Yogyakarta, masson thricrome (Bio-Optica_Italia).

\section{Test Animal}

The tested animals were male Wistar strain rats placed in individual cages maintained at room conditions of $25+ \pm 2{ }^{\circ} \mathrm{C}$ with a relative air humidity of $75 \%$. The weight control of the tested animals was carried out by weighing them from time to time. Tested animals' bodies weighed between $170-200 \mathrm{~g}$.

\section{Induction of animal diabetic try}

Experimental animals were induced with Streptozotocin (STZ) with a single dose of $45 \mathrm{mg} / \mathrm{kg}$. Induction was carried out by injection of i.p STZ solution in citrate buffer $(0.1 \mathrm{M}) \mathrm{pH} 4.5$. The $\mathrm{STZ}$ solution was made an hour before the induction by dissolving STZ in a cold buffer solution (Etuk, 2010).

\section{Measurement of blood glucose levels in experimental animals}

Glucose level measurements were performed after three days of induction with STZ. Blood sampling was done 4 days after STZ induction treatment. The rat blood was taken from the retro-orbital plexus, held in a $1.5 \mathrm{ml}$ microtube, and let standing for 30 minutes. Blood samples were centrifuged for 15 minutes at $4,000 \mathrm{rpm}$. The obtained serum was measured on its glucose levels based on the workings of the GOD FS reagent (Diasys ${ }^{\circledR}$ ). Blood sugar levels used in this study were $>200$ $\mathrm{mg} / \mathrm{dl}$ (Martsiningsih 2016).

\section{Wound making and measurement of test responses}

Experimental animals were anesthetized with ketamine injection at a dose of $50 \mathrm{mg} / \mathrm{kg}$ by administering intramuscular (i.m) (Kintoko, 2017). After the animal lost consciousness, the rat's back hair was shaved and wounded using a $5 \mathrm{~mm}$ diameter punch biopsy (Júnior et al., 2011).

\section{Grouping of Tested Animals}

Tested animals were grouped into five. Each group made replication of three tested animals. The division of the observation group is as follows: DM1 group: Basis Treatment; DM2 group: Formula 1 (F1) with extract content of $2.5 \%$; DM3 group: Formula 2 (F2) with extract content of 5\%; DM4 group: Formula 3 (F3) with extract content of $7.5 \%$; and DM5 group: No Treatment. Administration 
of preparations containing genistein gel was done every 12 hour in the morning and evening. The amount applied was as much as $\pm 25 \mathrm{mg}$ in the wound area.

Observation of collagen expression and epithelialization

Injured skin samples were fixed using $10 \%$ of formalin neutral buffer. Then, the sample was put in distilled water for 15 minutes and conditioned dehydrated with the addition of ethanol in stages; $70 \%, 80 \%$, and $96 \%$. The samples were clarified using xylol and printed on paraffin blocks. The slide cutting was done using a microtome with a thickness of 5-6 $\mu \mathrm{m}$. Paraffin pieces were stretched in warm water to prevent creases. The preparation was removed using a beaker and dried in $60^{\circ} \mathrm{C}$ oven. $\mathrm{HE}$ staining was carried out on preparations to evaluate closure of dermis tissue and perform the remodeling stage (Febram, 2010). Collagen observations were carried out by Masson
Thricrome staining based on the workings of the Masson Thricrome Goldner (Bio-Optica ${ }^{\circledR}$ ) kit (Suvik, 2012). Furthermore, observations were made using a microscope with a magnification of $10 \times 10$ times to see the collagen and epithelialization scores. The result is shown in Table 1.

\section{Observation of wound closure}

The observation of wound closure was done by measuring the diameter of the initial wound area and wound area on the day of observation. The diameter was obtained from the average of two wound areas on the right and left-back of the tested animal (Kintoko, 2017). The percentage measurements of wound closure (WC) were calculated using the following formula:

$\mathrm{WC}=\frac{\text { initial wound area }- \text { wound area on the day }}{\text { initial wound area }} \times 100 \%$

Table 1. Histological assessment

\begin{tabular}{ll}
\hline Parameter and description & Score
\end{tabular}

\section{The degree of collagen formation}

a. Collagen appears very dense/ small visual field (density <75\%) 4

b. Collagen appears solid/ small visual field (density $>50 \%-75 \%)$

c. Collagen appears to be less dense/ small visual field (density> 25\% -50\%) 2

d. Collagen appears to be very dense/ small visual field (density $<25 \% \quad 1$

\section{The degree of epithelialization}

a. High epithelialization/ microscope field of view 4

b. Normal epithelialization/ microscope field of view 3

c. Low epithelialization/ microscope field of view 2

d. There is no epithelialization/ microscope field of view 1

\section{Total new blood vessel formation}

a. More than 4 new blood vessels/ microscope field of view 4

b. 2-4 new blood vessels/ microscope field of view 3

c. 1-2 new blood vessels/ microscope field of view 2

d. There are no new blood vessels/ microscopic field of view 1 


\section{Data analysis}

The results of the research data were analyzed using the Shapiro-Wilk test to determine the normality of data distribution. If abnormal data distribution was found, a Kruskal-Wallis analysis was used and a significant difference in results was followed by a Post-Hoc Test

\section{RESULTS AND DISCUSSION}

\section{Blood glucose levels in experimental animals}

Diabetes in rat tested animals is a condition in which the rats have blood glucose levels above $200 \mathrm{mg} / \mathrm{dl}$. In this study measurements of serum blood levels of rats were carried out to measure blood glucose levels on day $0,3,7$ and 14. The blood sugar level tests on the animals within measurements of $0,3,7,14$ were $>200 \mathrm{mg} / \mathrm{dl}$. This condition was created to ensure that the tested animals experienced diabetes during wound healing test period.

High glucose level in diabetes has an effect on the wound healing process. High blood glucose causes decreasing neutrophils and macrophages migration leading to increasing potency for infection and prolongation of inflammatory conditions. The expression of TNF- $\alpha$ (Tumor Necrosis FactorAlpha) will increase during ulcers. The high TNF- $\alpha$ increases apoptosis and decreases fibroblast proliferation (Rosyid, 2016). Decreasing number of fibroblasts causes the synthesis of collagen in the wound area will also decrease. The high expression of MMP (Matrix Metalloproteinase) in a diabetes condition has worsen the wound healing process. MMP has cause some ECM (extracellular matrix) degradation including collagen.

\section{Response toward wound closure, collagen synthesis, epithelialization, and tissue capillarization}

The stages of the wound healing process are grouped into four stages namely, hemostasis, inflammation, proliferation, and remodeling (Velnar et al., 2009). Hemostasis stage occurs in the initial stage after the injury. Inflammation in the wound area is characterized by the increase of neutrophil and macrophage activity in the wound area. Formation of new blood vessels and fibroblasts occurs at the stage of proliferation. In addition, epithelial tissue begins to form from the edge of the wound. In the remodeling stage, collagen synthesized by fibroblasts will bond together and crowd increasingly. At this stage, the epithelial tissue forms thickens and closes the wound surface area (Baltzis et al., 2014).

The speed of wound closure is indicated by the closure of the wound surface caused by the process of epithelial cell formation on the wound surface. From the results of experiments on the gel base group, there are test subjects who did not experience the wound healing process. This condition is shown by the the size of the wound diameter which did not decrease. The highest rate of wound closure was achieved in the $7.5 \%$ extract gel group.

From the results of the measurement of wound closure speed, the calculation results are obtained as in Table 2 . The results of statistical analysis using the Kruskal-Wallis test ( $\mathrm{p}<$ 0.05 ) shows a significant difference in the treatment group of 5\% extract gel, and $7.5 \%$ extract gel against the group without treatment. In $2.5 \%$ extraction gel treatment group and base treatment group, there was no significant difference in the group without treatment.

Genistein is the main isoflavone compound contained in tempeh extract. The compound belongs to the phytoestrogen group found in soybean seeds. Estrogen affects the speed of wound closure by increasing mitogenesis and migration of keratinocytes. Estrogen interacts with Estrogen Receptor Beta $(E R \beta)$ thereby affecting the pattern of differentiation and proliferation activity of keratinocytes (Horng et al., 2017). Keratinocytes has migrated from the edge of the wound area to the center. Increased proliferation and migration activity of keratinocytes will accelerate the narrowing of the wound area resulting in wound closure. 
Table 2. Result of wound closure, collagen synthesis, epithelialization, and capillarization.

\begin{tabular}{lcccc}
\hline Group & $\begin{array}{c}\text { Wound Closure }(\%) \\
\pm \text { SD }\end{array}$ & Collagen Score \pm SD & $\begin{array}{c}\text { Epithelialization } \\
\text { Score } \pm \text { SD }\end{array}$ & $\begin{array}{c}\text { Capillarization Score } \pm \\
\text { SD }\end{array}$ \\
\hline DM1 & $16,23 \pm 4,07$ & $1,11 \pm 0,33$ & $6,00 \pm 2,64$ & $8,33 \pm 4,61$ \\
DM2 & $48,99 \pm 7,72$ & $1,22 \pm 0,44$ & $6,66 \pm 0,57$ & $9,66 \pm 3,21$ \\
DM3 & $91,89 \pm 14,05 *$ & $3,00 \pm 0,50^{*}$ & $7,33 \pm 2,31 *$ & $8,66 \pm 3,05$ \\
DM4 & $94,68 \pm 9,21^{*}$ & $3,67 \pm 0,50^{*}$ & $7,33 \pm 1,53 *$ & $7,66 \pm 3,21$ \\
DM5 & $33,82 \pm 10.30$ & $1,67 \pm 1,00$ & $5,00 \pm 1,73$ & $5,66 \pm 2,51$ \\
\hline
\end{tabular}

Information: *significant difference $(\mathrm{p}<0.05)$ to the DM5 group.

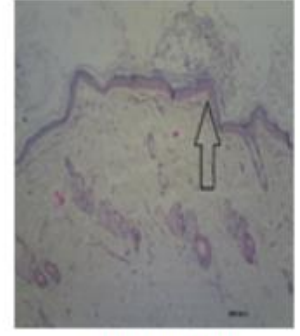

DM1 group

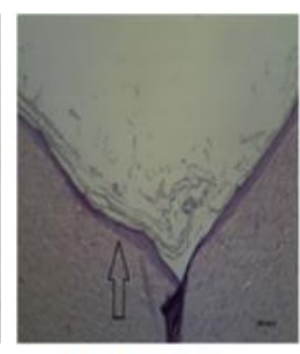

DM2 group

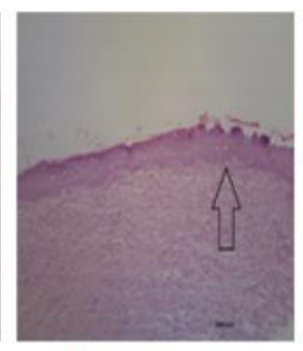

DM3 group

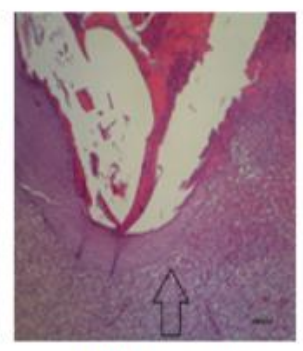

DM4 group

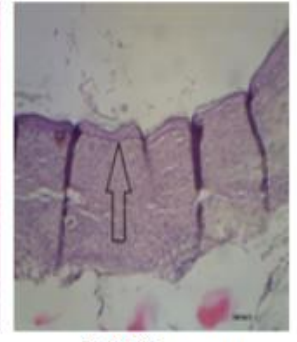

DM5 group

Figure 1. Microscopic images of epithelialization in each group

Histological observation of tissue samples was made to observe the wound healing process from the process of epithelial tissue formation, blood vessel formation, and collagen. This observation is followed by a scoring assessment of the formation of epithelial cells, blood vessels and collagen.

Wound closure can occur when epithelial cells, formed due to keratinocyte differentiation, migrate over the provisional matrix headed to the middle of the wound. Epithelial cells will meet in the middle area of the wound, so that cell migration will stop. Then, the formation of bacialis membrane will start accordingly. The thickness of the epithelial tissue is done by measuring the image using the help of image raster. The appearance of epithelial tissue can be shown by the arrows in Figure 1.

The results of statistical analysis using $(p<0.05)$ showed a significant difference in the degree of epithelialization from the formula $5 \%$ extract content and $7.5 \%$ extract content of the treatment group. Whereas in the test group with basis application, giving formula $2.5 \%$ extract content did not have significant differences in the group without treatment.
Giving tempeh extract with levels of 5\% and $7.5 \%$ extract contents has an influence on the degree of epithelialization in the wound healing process. Tempeh extract contains genistein which has a mechanism for increasing the degree of epithelialization that depends on keratinocyte cells, fibroblasts, and macrophages. Migration of epithelial cells into the wound surface is one of the keys in the process of re-epithelialization. The speed of cell migration is influenced by the presence of estrogen (Emmerson et al., 2010).

Formation of new blood vessels has a major role in the process of wound healing. The presence of blood vessels in the wound area will increase the wound healing process. Blood vessels contribute to the supply of blood, oxygen, and nutrients to the injured area. Blood vessels will be seen by the presence of red blood cells in the observation of histological preparations as shown in Figure 2. From the results of the study, there were no significant differences in the formation of blood vessels from each test group. Giving tempeh extract gel preparations in the base treatment group, levels of $2.5 \%, 5 \%$, and $7.5 \%$ extract content did not provide significantly different results compared to the group without treatment. 


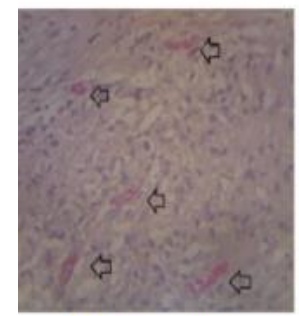

DM1 group

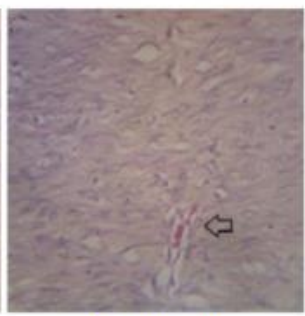

DM2 group

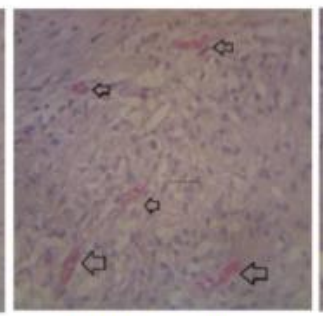

DM3 group

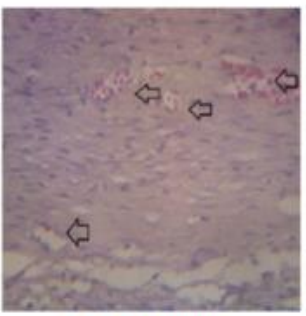

DM4 group

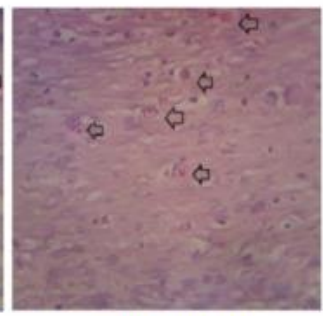

DM5 group

Figure 2. Capillary microscopic depictions of each group

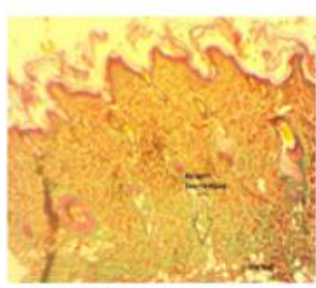

DM1 group

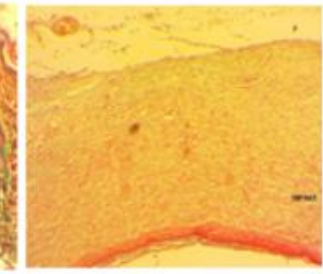

DM2 group

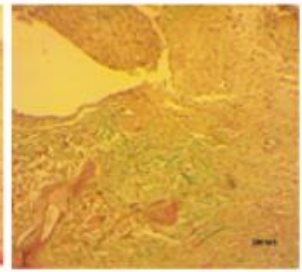

DM3 group

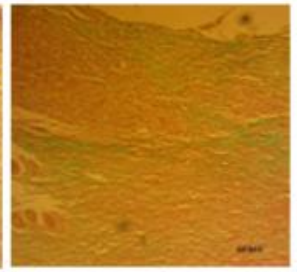

DM4 group

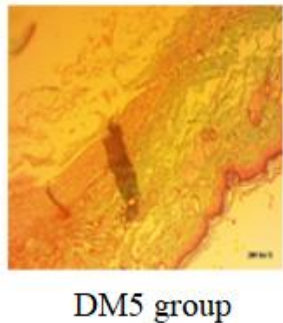

DM5 group

Figure 3. Microscopic picture of collagen in each group

Collagen is one of the proteins that make up the skin. Collagen fibers have a strong resistance to pressure. The more collagen found in the tissue, the stronger the tissue is against pressure. Collagen observations were carried out by staining using Masson Trichrome Goldner. The results of collagen staining provide a visualization of the green color in the histological preparations as shown in Figure 3. The more green color that appears shows the greater amount of collagen contained in the test tissue.

From the results of collagen analysis, it showed a significant difference in collagen expression in the test group. The $5 \%$ formula group and $7.5 \%$ extract content formula group had significant differences in the expression of collagen groups without treatment. The test group giving the basis and formula $2.5 \%$ extract content did not show any significant difference to the group without treatment.

The content of genistein contained in tempeh extract has an influence on collagen synthesis. From previous studies, genistein has an effect on collagen synthesis by binding to estrogen receptors and inhibiting tyrosine kinase (Irrera et al., 2017). The effect of genistein in tempeh extract on collagen synthesis is thought to be related to the mechanism of shortening the inflammatory phase so that the synthesis of fibroblasts in skin tissue increases. Fibroblasts are cells that produce collagen, so an increase in the number of fibroblasts in the tissue causes an increase in the amount of collagen.

In the condition of diabetes, the formed collagen is degraded due to high MMP in the tissue. The reduced amount of collagen will make the tissue more fragile. Hence, the wound that has been covered becomes more easily open again. With the high amount of collagen in the wound area, it is expected to increase the tissue's resistance to pressure on the skin.

From the results of testing, the wound closure using a gel base treatment, gel $2.5 \%$ tempeh extract content, gel 5\% tempeh extract content, gel 7.5\% tempeh extract content and without gel treatment, indicating the treatment group gel 5\% and $7.5 \%$ tempeh extract content treatment can affect diabetes wound healing in test animals. This is based on the results of the statistical test of the untreated group with the treatment group of gel 5\% tempeh extract content and $7.5 \%$ tempeh extract content treatment showing significantly different results in influencing the wound closure response, epithelialization and collagen formation. While the statistical results of the untreated group with the base treatment group without extracts and gel 2.5\% tempeh extract content treatment showed no significant difference in influencing the wound closure response, epithelialization and collagen formation. The results of statistical tests in 
influencing capillarization responses indicate the results were not significantly different from all treatment groups.

\section{CONCLUSION}

The results of testing the wound closure using a base gel treatment, gel $2.5 \%$ tempeh extract content, gel 5\% tempeh extract content, gel $7.5 \%$ tempeh extract content and without treatment, indicate that the treatment group gel 5\% tempeh extract content and $7.5 \%$ tempeh extract content treatment have a significant effect on diabetes wound healing in test animals based on the results of statistical tests. The untreated group with the treatment base gel without extract and gel 2.5\% tempeh extract content treatment showed no statistically significant test results in influencing the wound closure response, epithelialization and collagen formation. In addition, all treatment groups did not show significant capillarization responses.

\section{ACKNOWLEDGEMENT}

The authors would like to express their gratitude to the Directorate General of Higher Education (KEMENRISTEK DIKTI) for funding this research through the Master Thesis Research scheme with research contract No: 029 / Penel./ LPPM-USD / IV / 2019, and to Maria Yolanda Intansari and Yosua Hengky Purwanto for assisting the laboratory technicians in this research.

\section{REFERENCES}

Agrawal, S.S., Saxena, S., Sharma, A., 2015. Phytoestrogen " Genistein ": Its Extraction and Isolation from Soybean Seeds. International Journal of Pharmacognosy and Phytochemical Research, 7 (6), 11211126.

Anwar, K., 2018. Aktivitas Gel Ekstrak Etanol Umbi Akar Tawas Ut (Ampelocissus rubiginosa L .) Terhadap Penyembuhan Luka Insisi Pada Tikus Wistar. Traditional Medicine Journal, 23 (April), 30-39.

Baltzis, D., Eleftheriadou, I., Veves, A., 2014. Pathogenesis and Treatment of Impaired Wound Healing in Diabetes Mellitus: New Insights. Advances in Therapy, 31 (8), 817-836.
Emmerson, E., Campbell, L., Ashcroft, G.S., Hardman, M.J., 2010. The phytoestrogen genistein promotes wound healing by multiple independent mechanisms. Molecular and Cellular Endocrinology, 321 (2), 184-193.

Etuk, E.U., 2010. Animals models for studying diabetes mellitus Department of Pharmacology, College of Health Sciences, Usmanu Danfodiyo University,. Agriculture and Biology Journal of North America, 1 (2), 130-134.

Febram, B., 2010. Aktivitas sediaan salep ekstrak batang pohon pisang ambon (musa paradisiaca var sapientum) dalam proses persembuhan luka pada mencit (Mus musculus albinus), Majalah Obat Tradisional, 15(3), pp. 121-137.

Gupta, B., Agarwal, R., Alam, M.S., 2011. Hydrogels for wound healing applications.

Biomedical Hydrogels: Biochemistry, Manufacture and Medical Applications. Woodhead Publishing Limited.

Horng, H. et al., 2017. 'Estrogen Effects on Wound Healing', International Journal of Molecular science, pp. 1-14.

Irrera, N., Pizzino, G., Anna, R.D., Vaccaro, M., Arcoraci, V., Squadrito, F., Altavilla, D., Bitto, A., 2017. Dietary Management of Skin Health: The Role of Genistein. MDPI, 1-10.

Júnior, M.C.S., Colchon, P.H., Portes, A.G., 2011. Histological evaluation on Brazilian green propolis effect in tissue repair of wistar rats cutaneous wounds Histological Evaluation on Brazilian Green Propolis Effect in Tissue Repair of Wistar Rats Cutaneous Wounds, Lat. Am. J. Pharm. 30 (2): 383-7.

Kintoko, 2017. Effect of Diabetes Condition on Topical Treatment of Binahong Leaf Fraction in Wound Healing Process Pengaruh Kondisi Diabetes pada Pemberian Topikal Fraksi Daun Binahong dalam. Majalah Obat Tradisional, 22 (August), 103-110.

Martsiningsih, M.A., 2016. Gambaran Kadar Glukosa Darah Metode GOD-PAP (Glucose Oxsidase - Peroxidase Aminoantypirin) Sampel Serum dan 
Plasma EDTA (Ethylen Diamin Tetra Asetat), Jurnal Teknologi Laboratorium, Vol.5, No.1, Maret 2016, pp. 45-48.

Rosyid, F.N., 2016. Role of TNF- $\alpha$ in Diabetic Ulcer Healing Process. In: The 2nd International Conference on Science, Technology, and Humanity. 142-149.

Sharp, A.N.U., Jane, C., 2011. Diabetes and its effects on wound healing. Nursing Standard, 25 (45), 41-47.

Suvik, A., 2012. The Use Of Modified Masson's Trichrome Staining In Collagen Evaluation In Wound Healing Study, Malaysian Journal of Veterinary Research, Volume 3 No.1 January 2012, 39-47.

Tie, L., An, Y., Han, J., Xiao, Y., Xiaokaiti, Y., Fan, S., Liu, S., Chen, A.F., Li, X., 2013. Genistein accelerates refractory wound healing by suppressing superoxide and
FoxO1/iNOS pathway in type 1 diabetes. Journal of Nutritional Biochemistry, 24 (1), 88-96.

Utami, D.T., Karim, D., 2014. Diabetes mellitus dengan ulkus diabetikum, Jom Psik Vol. 1 No. 2 Oktober 2014, 1-7.

Utari, 2010. Tempe Terhadap Kadar Isoflavon, PGM 2010, 33(2): 148-153.

Velnar, T., Bailey, T., and Smrkolj, V., 2009. The wound healing process: An overview of the cellular and molecular mechanisms. Journal of International Medical Research, 37 (5), 1528-1542.

Yuliani, S.H., Gani, M.R., Istyastono, E.P., and Riswanto, F.D.O., 2018. Optimization of genistein and daidzein extraction from a tempeh-fermented product of soybean, Journal of Pharmacy \& Pharmacognosy Research, 6 (4), 231-241. 